\title{
Metal and metallothionein level in the heat-treated cytosol of gills of transplanted mussels Mytilus galloprovincialis Lmk.
}

Zrinka Dragun*, Marijana Erk, Biserka Raspor, Dušica Ivanković and Jasenka Pavičić

Ruđer Bošković Institute, Center for Marine and Environmental Research, POBox 180, 10002 Zagreb, Croatia

* phone: xx385-1-4680216;

fax: $\quad x x 385-1-4680242$;

e-mail: zdragun@rudjer.irb.hr

Abstract

A stock of mussels Mytilus galloprovincialis was transplanted over one year to four sites in a semi-enclosed bay in Croatia which is under the influence of various sources of pollution. The positive correlation of metal $(\mathrm{Cd}, \mathrm{Zn}, \mathrm{Cu}, \mathrm{Mn}, \mathrm{Fe})$ and metallothionein $(\mathrm{MT})$ tissue contents based on the analysis of heat-treated cytosol of gills with shell mass, as an indicator of mussel age, indicated to accumulation of metals, as well as the increase of MTs with mussel age. The principal component analysis (PCA) revealed that $74 \%$ of total variance of obtained results could be explained through two principal components. The first principal component was highly correlated with MT, Cd and Zn indices (metal or MT content/shell mass), and the second one with $\mathrm{Cu}, \mathrm{Mn}$, and Fe indices, as well as the gill index. High correlation of MTs with $\mathrm{Zn}$ and $\mathrm{Cd}$ is consistent with their affinity for binding to MTs.

Key words: Mytilus galloprovincialis; trace metals; metallothionein; cytosol; gills 
Introduction

Mussels are widely used as bioindicators of heavy metal pollution in coastal waters because as filter-feeders they accumulate various elements (Regoli, 1998). The accumulated trace metals in an aquatic invertebrate can be interpreted in terms of metabolically available and detoxified forms of metals (Rainbow, 2002). Heavy metals are more concentrated in the gills and in the viscera than in the mantle and adductor muscle of mussels (Denton and BurdonJones, 1981). During gametogenesis, gonad tissue develops within the mantle and the digestive gland influencing total mass, but similar effect is not observed for gills (Regoli, 1998). Gills are known to change only slightly in their tissue mass during the mussel reproductive cycle. Any significant change of gill mass could only be the consequence of somatic growth of mussels (Martinčić, 1987).

Metabolism of metals in mussels is organ specific, and reflects the function of the respective organ, i.e. the processes which take place in it, and is influenced by season, environmental conditions and requirements for certain amounts of metals during somatic growth and reproduction. In gills of mussels, metals are accumulated considerably more rapidly compared to organ growth, leading to metal storage in gill tissue (Martinčić, 1987). It could be the consequence of the excretion of the mucous material by gills which may be involved in trace metal uptake from the dissolved as well as from the particulate phase due to its strong chelating ability (Korringa, 1952).

Furthermore, as in other filter-feeders, MT response is most significant in the gills of mussels, as the respiratory organ and organ for filtering seawater, and this tissue is, therefore, probably the most appropriate for assay. Gills function as both a site for metal uptake, and as an 
important reservoir for metal storage, and MT sequesters a significant proportion of accumulated $\mathrm{Cd}, \mathrm{Cu}$ and $\mathrm{Hg}$ (Langston et al., 1998).

Thus, among organs of mussels Mytilus galloprovincialis Lmk. transplanted to the semienclosed Kaštela Bay in Croatia, the gills were chosen as a target organ, to observe possible accumulation of metals and increase of MTs during one year, as well as the seasonal dependence of that occurrence. An additional objective was to determine if significant differences in metal and MT levels exist at the four transplant stations.

Materials and Methods

\section{Mussel caging and sampling}

Filter-feeding $\underline{M}$. galloprovincialis of defined length $(5.1 \pm 0.2 \mathrm{~cm})$ and age $(12 \pm 1$ months $)$ were transplanted from an aquaculture area (the shellfish breeding farm in Mali Ston Bay) and caged at 4 different sites within Kaštela Bay, Croatia (Fig. 1, sites A to D), a recipient of untreated urban and industrial wastewater (Barić et al., 1992). The caging locations were 50 to $400 \mathrm{~m}$ distant from the shore. At each caging site 8 net-like baskets (each one containing 50 specimens) were deployed $1.5 \mathrm{~m}$ above the sea bottom on September $15^{\text {th }} 1997$; one basket was sampled at a time. Monthly sampling was performed in October, November and December 1997, to detect any changes which might reflect the acclimation of Mediterranean mussels to new ambient conditions. In 1998 bimonthly sampling was performed (February, April, June, August). The last one took place in September 1998 to end up the round. Within current month, sampling took place on the same date as the deployment date. At stations A and B sampling was complete (8 times), while due to rough weather at site $\mathrm{C}$ one sampling 
and at site D two samplings were not accomplished. Therefore, data at these two locations in particular periods are missing.

\section{[Figure 1]}

After sampling, mussels were kept for 24 hours in the filtered $(0.45 \mu \mathrm{m})$ seawater to depurate the gut content (Bordin et al., 1992; Odžak et al., 2000), and than transported to the Laboratory in Zagreb, where biometry and tissue dissection took place. Composite samples of mussel tissues were deep frozen at $-80^{\circ} \mathrm{C}$ until further processing and analysis.

\section{$\underline{\text { Mussel biometry }}$}

At each caging site and sampling period the composite sample of the gills was made up on average from 28 specimens. Therefore, no replicates per sampling period and site exist, but results represent the average biochemical and chemical responses. Average gill mass within composite tissue sample was determined in order to observe temporal fluctuations of that tissue, mainly related to reproductive cycle and food availability (Bordin et al., 1997). At the beginning of our field study the mussels' age was defined as $12 \pm 1$ months. Shell mass was selected as additional indicator of age, due to the fact that the calcareous shell continues to be formed even when the length increments are not observed (Fischer, 1983). Our observations confirm that during 12 months of caging, mussels' length increased on average from 5.2 to 5.9 $\mathrm{cm}$, while the shell mass increased on average from 4.5 to $7.0 \mathrm{~g}$.

\section{$\underline{\text { Homogenate and cytosolic fraction }}$}

Composite gill tissue was homogenised in three volumes of $0.02 \mathrm{M}$ TRIS-HCl buffer, $\mathrm{pH}=8.6$, containing leupeptine $(0.006 \mathrm{mM})$, phenylmethyl-sulphonylfluoride (PMSF, 0.5 
$\mathrm{mM})$ and 2-mercaptoethanol $(0.01 \%)$, on an ice-bath with a Potter-Elvehjem type of homogenizer. The homogenate was centrifuged in the Sorval RC28S centrifuge by Du Pont at $30000 \mathrm{xg}$ for 40 minutes at $4^{\circ} \mathrm{C}$. The isolated supernatant (S30) contained total cytosolic proteins (Yang et al., 1995). Further on, S30 was heat-treated at $70^{\circ} \mathrm{C}$ for 10 minutes using The Dri Block (Techne), and subsequently centrifuged at $30000 \mathrm{xg}$ for 20 minutes at $4^{\circ} \mathrm{C}$. This supernatant contained MTs as heat-stable cytosolic proteins (Yang et al., 1995).

\section{$\underline{\text { MT and trace metal concentrations in the heat-treated cytosol of gills }}$}

MT concentration $(\mathrm{mg} / \mathrm{ml})$ in the heat-treated supernatant was determined by electrochemical method in a differential pulse mode (Raspor et al., 2001), on a Metrohm 290E hanging mercury drop electrode (HMDE), on $\mu$ Autolab (Eco Chemie, The Netherlands). MT calibration straight line was obtained at $7^{\circ} \mathrm{C}$ with the commercial rabbit liver MT(I+II) from Sigma.

Metal concentrations $(\mu \mathrm{g} / \mathrm{ml})$ were also determined in the heat-treated S30 fraction of gills, to obtain data only on the fraction of metals that is bound to MTs. That fraction does not represent total metal content in gills of mussels, and thus is not comparable to tissue digested metal content frequently reported as monitoring parameter.

Varian double beam flame atomic absorption spectrometer (SpectrAA 220) with multielement lamps and a deuterium lamp for baseline correction was used for metal analyses in heattreated S30 fractions. Atomisation of metals was achieved in the air-acetylene flame. Calibration was performed using Merck's standard solutions of $\mathrm{Cd}, \mathrm{Zn}, \mathrm{Cu}, \mathrm{Mn}$ and $\mathrm{Fe}$ prepared in Tris- $\mathrm{HCl}$ buffer of the same concentration $(0.004 \mathrm{M})$ as the diluted samples. 
Detection limits of the selected metals were as follows: $\mathrm{Cd} 0.003 \mu \mathrm{g} / \mathrm{ml} ; \mathrm{Zn} 0.012 \mu \mathrm{g} / \mathrm{ml} ; \mathrm{Cu}$ $0.002 \mu \mathrm{g} / \mathrm{ml} ; \mathrm{Mn} 0.002 \mu \mathrm{g} / \mathrm{ml}$; and Fe $0.009 \mu \mathrm{g} / \mathrm{ml}$.

Mass partition of MTs and metals in gills was expressed on a wet tissue mass basis $(\mathrm{mg} / \mathrm{g}$ and $\mu \mathrm{g} / \mathrm{g}$, respectively), multiplying concentrations determined in the heat-treated cytosol of gills by a factor of four which corresponds to homogenate dilution. Contents of MTs and metals (mg and $\mu \mathrm{g}$, respectively) were obtained by multiplying their mass partition by the wet gill mass. MT and metal indices were obtained by dividing MT and metal content by the shell mass.

$\underline{\text { Statistical treatment of results }}$

All statistical analyses (descriptive statistics, Kruskal-Wallis test, correlation matrix, two-way ANOVA) were performed in SigmaStat for Windows Version 1.0, except the principal component analysis (PCA), which was performed in SPSS ${ }^{\circledR} 10.0$ for Windows.

Results and Discussion

\section{$\underline{\text { MT and metal mass partition in the heat-treated cytosol of gills }}$}

The median and the range of MT and metal mass partition based on the analysis of heattreated cytosol of gills, as well as the gill and shell mass, are shown in Table 1. Zinc was present in the highest mass partition (median $\approx 2.5-3.5 \mu \mathrm{g} / \mathrm{g}$ ), followed by $\mathrm{Fe}$ (median $\approx 2.0$ $\mu \mathrm{g} / \mathrm{g}), \mathrm{Mn}($ median $\approx 0.6-0.7 \mu \mathrm{g} / \mathrm{g}), \mathrm{Cu}($ median $\approx 0.4-0.5 \mu \mathrm{g} / \mathrm{g})$ and $\mathrm{Cd}($ median $\approx 0.1 \mu \mathrm{g} / \mathrm{g})$. Kruskal-Wallis test showed no statistically significant differences between the four stations regarding any of analysed variables, although at the station $\mathrm{C}$ higher mass partitions of $\mathrm{Cd}$ and 
especially of $\mathrm{Zn}$ were observed in comparison with other stations, which could be in some connection with the larger gills found in mussels at that station.

Median MT mass partition expressed on wet tissue mass amounts to $0.46 \mathrm{mg} / \mathrm{g}$. In order to compare our results with those reported by other authors, the MT level has to be expressed on dry tissue mass. Serafim et al. (2002) reported basal MT levels in gills of Mytilus galloprovincialis from $2.2 \pm 0.03$ to $3.8 \pm 0.9 \mathrm{mg} / \mathrm{g}$ (dry mass), with higher values obtained at higher temperature. Similarly, Bebianno and Serafim (1998) earlier reported mean MT mass partition in unexposed gills of the mussels Mytilus galloprovincialis as $2.5 \pm 0.8 \mathrm{mg} / \mathrm{g}$. Our median MT value $(0.46 \mathrm{mg} / \mathrm{g}$, wet mass $)$ was corrected to dry tissue mass applying fresh to dry tissue ratio of the whole soft tissue (median value $=8.1$ ). Consequently, estimated MT level expressed on dry tissue mass amounts to $3.73 \mathrm{mg} / \mathrm{g}$. Thus, MT level determined in the gills of mussels Mytilus galloprovincialis in Kaštela Bay is comparable to the basal MT level reported by Serafim et al. (2002).

\section{[Table 1]}

\section{$\underline{\text { Temporal variation of analysed parameters }}$}

By means of Pearson's coefficient and linear regression analysis, the correlation between shell mass as an indicator of mussel's growth due to ageing, and the content of metals and MTs was determined (Figure $2 \mathrm{a}, \mathrm{b}$ and c). Positive correlation of all metals, as well as MTs with the shell mass, which was statistically significant in all cases, except for $\mathrm{Cu}$, was observed. It is obvious that the growth of the organism was followed by an increase in metal content. At the same time, positive correlation of MTs with the shell mass, indicates that MT content also increased during one year of mussel deployment, either due to metal accumulation or mussel's 
growth. Odžak et al. (1994) have previously shown that the total Cd concentration in the gills increases with mussel age, while Serafim et al. (2002) reported significantly higher MT content in larger, i.e. older, mussels exposed to $\mathrm{Cd}$.

[Figure $2 \mathrm{a}, \mathrm{b}, \mathrm{c}$ ]

Linear regression analysis and Pearson's coefficient showed relatively strong dependence of gill mass on shell mass $(\mathrm{r}=0.57, \mathrm{p}<0.01)$ (Figure 3$)$, too. This correlation indicates that gills are growing concurrently with the shell, i.e. with the mussel age.

[Figure 3]

\section{The effect of season on metal and MT level in the gills}

In the next step, the content of metals and MTs, as well as the gill mass, were divided by shell mass and expressed as indices, in order to reduce the effect of mussel's growth and to observe the seasonal changes of metal and MT contents, and of the gill mass, at each deployment site (A to D). Gills of mussels Mytilus galloprovincialis were selected as the target organ for metal and MT analyses, based on the results of previous studies that showed gills to be an organ which demonstrates the least seasonal variability (Martinčić et al., 1987; Regoli, 1998). The fluctuations of gill index were observed during the year, with somewhat higher values in November, i.e. late autumn (Figure 4). But, since maxima at different stations do not overlap in the same period of the year, it is more probable that variability in gill mass is the result of different food availability at different stations, during certain period of the year, than the consequence of the reproductive cycle. This is especially characteristic for the late autumn in the semi-enclosed Kaštela Bay, when the resuspension of sediment by the action of wind and 
waves was more intense, resulting in the higher content of suspended particles in the water column (Odžak et al., 2000). Higher food availability leads to increased somatic growth, considering that mussel branchial cells are also involved in the food uptake (Regoli, 1998).

\section{[Figure 4]}

Table 2 shows the correlation matrix for metal, MT and gill indices. Strong, statistically significant correlation $(\mathrm{p}<0.001)$ is present between MT, Zn and Cd. Furthermore, another group of parameters $(\mathrm{Cu}, \mathrm{Mn}$ and $\mathrm{Fe})$ correlates moderately, but statistically significantly with each other. All the parameters correlate positively and statistically significantly with the gill index, except Cd. Regoli (1998) already reported that the Fischer metal index (total metal content/shell mass) of $\mathrm{Zn}, \mathrm{Cu}, \mathrm{Mn}$ and $\mathrm{Fe}$ was significantly increased with increased gill mass.

[Table 2]

To additionally confirm the separation of parameters into two groups, as indicated in Table 2, PCA was performed (Figure 5). Two principal components were extracted explaining $74 \%$ of total variance (each component explains approximately $37 \%$ of total variance), where MT, Zn and $\mathrm{Cd}$ showed striking correlation with the first component, and $\mathrm{Cu}, \mathrm{Mn}$ and $\mathrm{Fe}$ with the second one. Grouping of MTs with Zn and Cd could be explained by well known Zn and Cd potential of MT induction (Langston et al., 1998). Gill index correlates with both components, but inclines towards the second one.

[Figure 5] 
It could be hypothesised that separation of metals into two groups reflects two different chemical forms of metals in the ambient water. On the basis of high correlation of gill index with the same principal component that strongly influences $\mathrm{Cu}, \mathrm{Mn}$ and Fe indices, it could be presumed that the uptake of these three metals to gills predominantly occurs via the particulate form of metals from the ambient water, i.e. via the food uptake. On the other hand, bioavailability of $\mathrm{Cd}$ and $\mathrm{Zn}$ to mussels is more often connected with the dissolved form of the metals. As concentrations of metals in water were not determined in the course of our study, this hypothesis could only be discussed on the basis of some previously reported studies. For example, $\mathrm{Cd}$ and $\mathrm{Zn}$ in seawater are predominantly present as the labile ionic complexes (Ahrland, 1988) and the uptake route of trace metals by gills is mainly from the dissolved state (Cossa, 1989). The content of $\mathrm{Zn}$ in gills is mostly influenced by soluble $\mathrm{Zn}$ in water, as shown by Popham and D'Auria (1982), while Odžak et al. (1994) reported that the total Cd level in mussel gills is highly dependent on the concentration of this metal in the surrounding seawater. Furthermore, Odžak et al. (2001) reported the results from the Kaštela Bay for the period from 1997 to 1998, which showed that Cd and $\mathrm{Zn}$ concentrations in investigated organs of mussels (gills and digestive gland) were not related to the concentrations of those metals in the underlying sediments.

Seasonal variability of MT, $\mathrm{Zn}$ and $\mathrm{Cd}$ indices was observed at each deployment station (Figure 4). Two seasons were resolved: the autumn season of high MT indices (in November), which could not be confirmed for metals due to the lack of samples for metal determination in that period; and the summer season of both elevated MT and metal indices during the period from June to August. Two way ANOVA was also performed to confirm this seasonal dependence of MT and metal $(\mathrm{Cd}, \mathrm{Zn})$ indices of the gills. Both seasons for MTs, and the 
summer season for Cd statistically significantly $(\mathrm{p}<0.05)$ differ from the rest of the year, while $\mathrm{Zn}$ indices, although higher during summer, were not statistically significantly different from the rest of the year $(p=0.2)$. Serafim et al. (2002) reported that MT expression in gills of Cd-exposed mussels was significantly higher at higher temperature, while similar temperature dependent Cd accumulation was reported by Serra et al. (1999). Greater Cd accumulation during the summer months was also observed in the study on Crassostrea virginica as a sentinel organism (Zaroogian, 1980). It could be, thus, presumed that during summer season accumulation of $\mathrm{Zn}$ and $\mathrm{Cd}$ was increased in gills, either as a result of higher availability of these metals in the dissolved state, higher temperature of seawater, or due to the increase of the diffusion rate, consequently leading to MT induction.

But, as seen on Figure 5, there is also an important impact of gill index on MT, Zn and Cd. Although the influence of season on $\mathrm{Zn}, \mathrm{Cd}$ and MT prevails, the changes in the gill index are causing the occurrence of the irregularities in the seasonal dependence of these parameters. For example, a decrease in gill index towards summer at station D makes the summer maximum less visible, while the increase in gill index towards summer at station $\mathrm{C}$ makes that station the place with the strongest seasonal impact (Figure 4). Existence of statistically significant interactions between season and station was also determined by two way ANOVA, showing that the intensity of the seasonal effect on MT, Zn and Cd depended on the mussel deployment site.

\section{Conclusions}

The gills of mussels transplanted from the aquaculture site (Mali Ston Bay) to the semienclosed Kaštela Bay, Adriatic Sea, Croatia, were selected as a target organ to observe the 
effects of mussel exposure to metals ( $\mathrm{Cd}, \mathrm{Zn}, \mathrm{Cu}, \mathrm{Mn}$ and $\mathrm{Fe}$ ) by means of MTs. Mussel deployment at four stations lasted 12 months, and during that time it became evident that content of all analysed metals, based on the analyses of heat-treated cytosol of composite sample of gills, has increased, following both the increase of gill index, and the growth of the mussels. At the same time, MT content was enhanced, probably as a result of both mussel's growth and the metal accumulation.

According to a correlation matrix and PCA, metal indices of the gills have partitioned into two groups, reflecting two different chemical forms of taken up metals. One group comprised $\mathrm{Zn}$ and $\mathrm{Cd}$, predominantly available in the dissolved phase, and the other one $\mathrm{Cu}, \mathrm{Mn}$ and $\mathrm{Fe}$, predominantly available from the particulate phase. High correlation of MTs with Zn and Cd is consistent with their affinity for binding to MTs. The intensity of the observed seasonal effect on MT, Cd and Zn depends on the gill index of mussels deployed at different stations within the Bay, as the consequence of variable food availability.

\section{Acknowledgements}

Ministry of Science and Technology, Republic of Croatia, is acknowledged for the financial support of the research project 0098130 "Metals and cellular biomarkers". Additional acknowledgement to Dr. N. Odžak for the deployment of caged mussels and to Dr. M. Erk for mussel sampling and transport to Zagreb. 
References

Ahrland, S. Trace metals complexation by inorganic ligands in sea water. In: West, T.S.; Nurnberg, H.W. eds. The determination of trace metals in natural waters. Oxford: Blackwell Scientific Publications; pp. 233-253; 1988.

Barić, A.; Marasović, I.; Gačić, M. Eutrophication phenomenon with special reference to the Kaštela Bay. Chem. Ecol. 6:51-68; 1992.

Bebianno, M.J.; Serafim, M.A. Comparison of metallothionein induction in response to cadmium in the gills of the bivalve molluscs Mytilus galloprovincialis and $\underline{\text { Ruditapes }}$ decussatus. Sci. Total Environ. 214:123-131; 1998.

Bordin, G.; McCourt, J.; Rodriguez, A.R. Trace metals in the marine bivalve Macoma baltica in the Westerschelde Estuary (The Netherlands). Part 1: Analysis of total copper, cadmium, zinc and iron concentrations-Locational and seasonal variations. Sci. Total Environ. 127:255-280; 1992.

Bordin, G.; McCourt, J.; Cordeiro-Raposo, F.; Rodriguez, A.R. Metallothionein-like metalloproteins in the baltic clam Macoma balthica: seasonal variations and induction upon metal exposure. Mar. Biol. 129:453-463; 1997.

Cossa, D. A review of the use of Mytilus spp. as quantitative indicators of cadmium and mercury contamination in coastal waters. Oceanol. Acta 12:417-432; 1989.

Denton, G.R.W.; Burdon-Jones, C. Influence of temperature and salinity on the uptake, distribution and depuration of mercury, cadmium and lead by the black-lip oyster

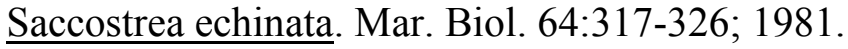

Fischer, H. Shell weight as an independent variable in relation to cadmium content of molluscs. Mar. Ecol. Prog. Ser. 12:59-75; 1983.

Korringa, P. Recent advances in oyster biology. Q. Rev. Biol. 27:266-308; 1952. 
Langston, W.J.; Bebianno, M.J.; Burt, G.R. Metal handling strategies in molluscs. In: Langston, W.J.; Bebianno, M.J., eds. Metal metabolism in aquatic environments. London: Chapman \& Hall; pp. 219-283; 1998.

Martinčić, $\mathrm{D}$. PhD Thesis, The distribution of $\mathrm{Cu}, \mathrm{Pb}, \mathrm{Zn}$ and $\mathrm{Cd}$ between mussels (Mytilus galloprovincialis, Lmk.), oysters (Ostrea edulis, linnaeus) and water of Lim channel. Zagreb: University of Zagreb; 374 pp (in Croatian); 1987.

Martinčić, D.; Nurnberg, H.W.; Branica, M. Bioaccumulation of metals by bivalves from the Limski Kanal (North Adriatic Sea). III. Copper distribution between Mytilus galloprovincialis (Lmk.) and ambient water. Sci. Total Environ. 60:121-142; 1987.

Odžak, N.; Martinčić, D.; Zvonarić, T.; Branica, M. Bioaccumulation rate of $\mathrm{Cd}$ and $\mathrm{Pb}$ in Mytilus galloprovincialis foot and gills. Mar. Chem. 46:119-131; 1994.

Odžak, N.; Zvonarić, T.; Kljaković Gašpić, Z.; Horvat, M.; Barić, A. Biomonitoring of mercury in the Kaštela Bay using transplanted mussels. Sci. Total Environ. 261:61-68; 2000.

Odžak, N.; Zvonarić, T.; Kljaković Gašpić, Z.; Barić, A. Biomonitoring of copper, cadmium, lead, zinc and chromium in the Kaštela Bay using transplanted mussels. Fresenius Environ. Bull. 10:37-41; 2001.

Popham, J.D.; D'Auria, J.M.; Effects of season and seawater concentrations on trace metal concentration in organs of Mytilus edulis. Arch. Environ. Contam. Toxicol. 11:273$282 ; 1982$.

Rainbow, P.S. Trace metal concentrations in aquatic invertebrates: why and so what? Environ. Pollut. 120:497-507; 2002.

Raspor, B.; Paić, M.; Erk, M. Analysis of metallothioneins by the modified Brdička procedure. Talanta 55:109-115; 2001. 
Regoli, F. Trace metals and antioxidant enzymes in gills and digestive gland of the Mediterranean mussel Mytilus galloprovincialis. Arch. Environ. Contam. Toxicol. $34: 48-63 ; 1998$.

Serafim, M.A.; Company, R.M.; Bebianno, M.J.; Langston, W.J. Effect of temperature and size on metallothionein synthesis in the gill of Mytilus galloprovincialis exposed to cadmium. Mar. Environ. Res. 54:361-365; 2002.

Serra, R.; Isani, G.; Tramontano, G.; Carpene, E. Seasonal dependance of cadmium accumulation and Cd-binding proteins in Mytilus galloprovincialis exposed to cadmium. Comp. Biochem. Physiol., C 123:165-174; 1999.

Yang, M.S.; Chiu, S.T.; Wong, M.H. Uptake, depuration and subcellular distribution of cadmium in various tissues of Perna viridis. Biomed. Environ. Sci. 8:176-185; 1995.

Zaroogian, G.E. Crassostrea virginica as an indicator of cadmium pollution. Mar. Biol. $58: 275-284 ; 1980$. 
Figure Captions

Figure 1 Study area of the semi-enclosed Kaštela Bay in Croatia, and the mussel deployment sites A to D.

Figure 2 Linear regression graphs for shell mass vs. metal and MT contents based on the analyses of the heat-treated cytosol of gills of the mussels, deployed 12 months in Kaštela Bay, Croatia, comprising the data from all four sites: a) MT and Cd; b) Zn and Fe; and c) $\mathrm{Cu}$ and Mn.

Figure 3 Linear regression graph for gill mass vs. shell mass of the mussels deployed 12 months in Kaštela Bay, Croatia, comprising the data from all four sites.

Figure 4 Temporal distribution of gill index, and MT, Zn, and Cd indices of mussels deployed at particular stations (A, B, C and D) in the Kaštela Bay, Croatia. Legend: $\diamond$ Gill index; ( Cd index; I Zn index; $\int \mathrm{MT}$ index. Arrows are pointing at late autumn (November) and summer (June-August) maxima.

Figure 5 Principal component analysis graph with Varimax rotation and Kaiser normalisation for indices of MTs, $\mathrm{Cd}, \mathrm{Zn}, \mathrm{Cu}, \mathrm{Mn}, \mathrm{Fe}$ and gills. 
Table 1. Median, minimum and maximum of the gill mass, shell mass and mass partition of MTs and metals $(\mathrm{mg} / \mathrm{g}$ and $\mu \mathrm{g} / \mathrm{g}$ wet mass (wm), respectively) based on the analysis of heat-treated cytosol (S30) of gills of the mussels Mytilus galloprovincialis deployed over 12 months at four stations (viz. Figure 1) into Kaštela Bay in Croatia.

\begin{tabular}{|c|c|c|c|c|c|c|c|c|}
\hline & $\begin{array}{c}\text { Gill mass } \\
\text { (g wm) }\end{array}$ & $\begin{array}{c}\text { Shell mass } \\
\text { (g) }\end{array}$ & $\begin{array}{c}\text { MT } \\
\text { (mg/g wm) }\end{array}$ & $\begin{array}{c}\text { Cd } \\
(\mu \mathrm{g} / \mathrm{g} \text { wm) }\end{array}$ & $\begin{array}{c}\mathrm{Zn} \\
(\mu \mathrm{g} / \mathrm{g} \text { wm) }\end{array}$ & $\begin{array}{c}\mathrm{Cu} \\
(\mu \mathrm{g} / \mathrm{g} \mathrm{wm})\end{array}$ & $\begin{array}{c}\text { Mn } \\
(\mu \mathrm{g} / \mathrm{g} \mathbf{w m})\end{array}$ & $\begin{array}{c}\text { Fe } \\
(\mu \mathrm{g} / \mathrm{g} \mathrm{wm})\end{array}$ \\
\hline & Median & Median & Median & Median & Median & Median & Median & Median \\
\hline & Min-Max & Min-Max & Min-Max & Min-Max & Min-Max & Min-Max & Min-Max & Min-Max \\
\hline \multirow[t]{2}{*}{ Station A } & 0.56 & 5.94 & 0.44 & 0.12 & 2.53 & 0.52 & 0.63 & 1.77 \\
\hline & $0.41-0.59$ & $4.59-6.81$ & $0.34-0.62$ & $0.05-0.20$ & $1.72-4.07$ & $0.32-0.95$ & $0.50-0.78$ & $1.24-2.13$ \\
\hline \multirow[t]{2}{*}{ Station B } & 0.51 & 5.95 & 0.47 & 0.13 & 2.78 & 0.54 & 0.69 & 2.03 \\
\hline & $0.42-0.68$ & $4.20-8.04$ & $0.32-0.66$ & $0.10-0.17$ & $1.92-3.75$ & $0.41-0.79$ & $0.60-0.95$ & $1.54-2.47$ \\
\hline \multirow[t]{2}{*}{ Station C } & 0.61 & 5.74 & 0.45 & 0.14 & 3.67 & 0.47 & 0.66 & 2.02 \\
\hline & $0.50-0.81$ & $4.31-6.80$ & $0.36-0.57$ & $0.12-0.21$ & $2.80-4.32$ & $0.39-0.71$ & $0.61-0.82$ & $1.45-2.36$ \\
\hline \multirow[t]{2}{*}{ Station D } & 0.57 & 6.17 & 0.54 & 0.12 & 2.67 & 0.40 & 0.58 & 1.82 \\
\hline & $0.42-0.72$ & $4.29-6.76$ & $0.31-0.68$ & $0.10-0.18$ & $2.09-5.53$ & $0.31-0.50$ & $0.56-0.73$ & $1.35-2.16$ \\
\hline
\end{tabular}


Table 2. Pearson's correlation coefficients of MT and metal indices (content/shell mass) and gill index, comprising the data from all four deployment sites in Kaštela Bay

\begin{tabular}{|ccccccc|}
\hline $\begin{array}{c}* \mathrm{p}<0.05 \\
* * \mathrm{p}<0.01 \\
* * * \mathrm{p}<0.001\end{array}$ & $\mathbf{M T}$ & $\mathbf{C d}$ & $\mathbf{Z n}$ & $\mathbf{C u}$ & $\mathbf{M n}$ & $\mathbf{F e}$ \\
\hline $\mathbf{M T}$ & 1.00 & & & & & \\
\hline $\mathbf{C d}$ & $0.71^{* * *}$ & 1.00 & & & & \\
\hline $\mathbf{Z n}$ & $0.66^{* * *}$ & $0.79^{* * *}$ & 1.00 & & & \\
\hline $\mathbf{C u}$ & 0.04 & 0.02 & 0.02 & 1.00 & & \\
\hline $\mathbf{M n}$ & 0.05 & 0.15 & 0.31 & $0.48^{*}$ & 1.00 & \\
\hline $\mathbf{F e}$ & -0.11 & -0.10 & 0.05 & $0.46^{*}$ & $0.54^{* *}$ & 1.00 \\
\hline Gill index & $0.46^{*}$ & 0.40 & $0.46^{*}$ & $0.44^{*}$ & $0.76^{* * *}$ & $0.48^{*}$ \\
\hline
\end{tabular}




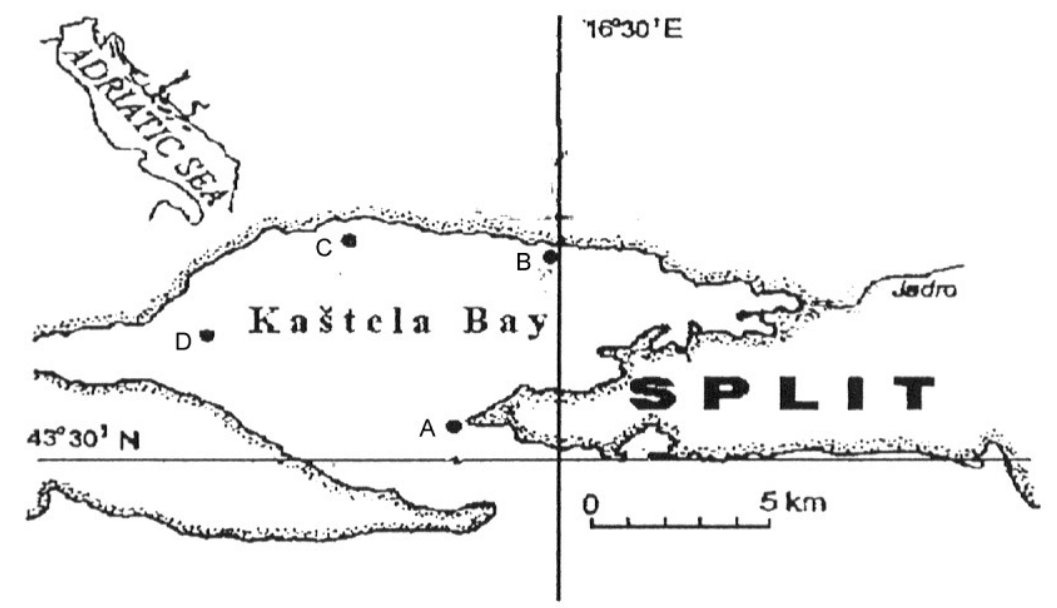



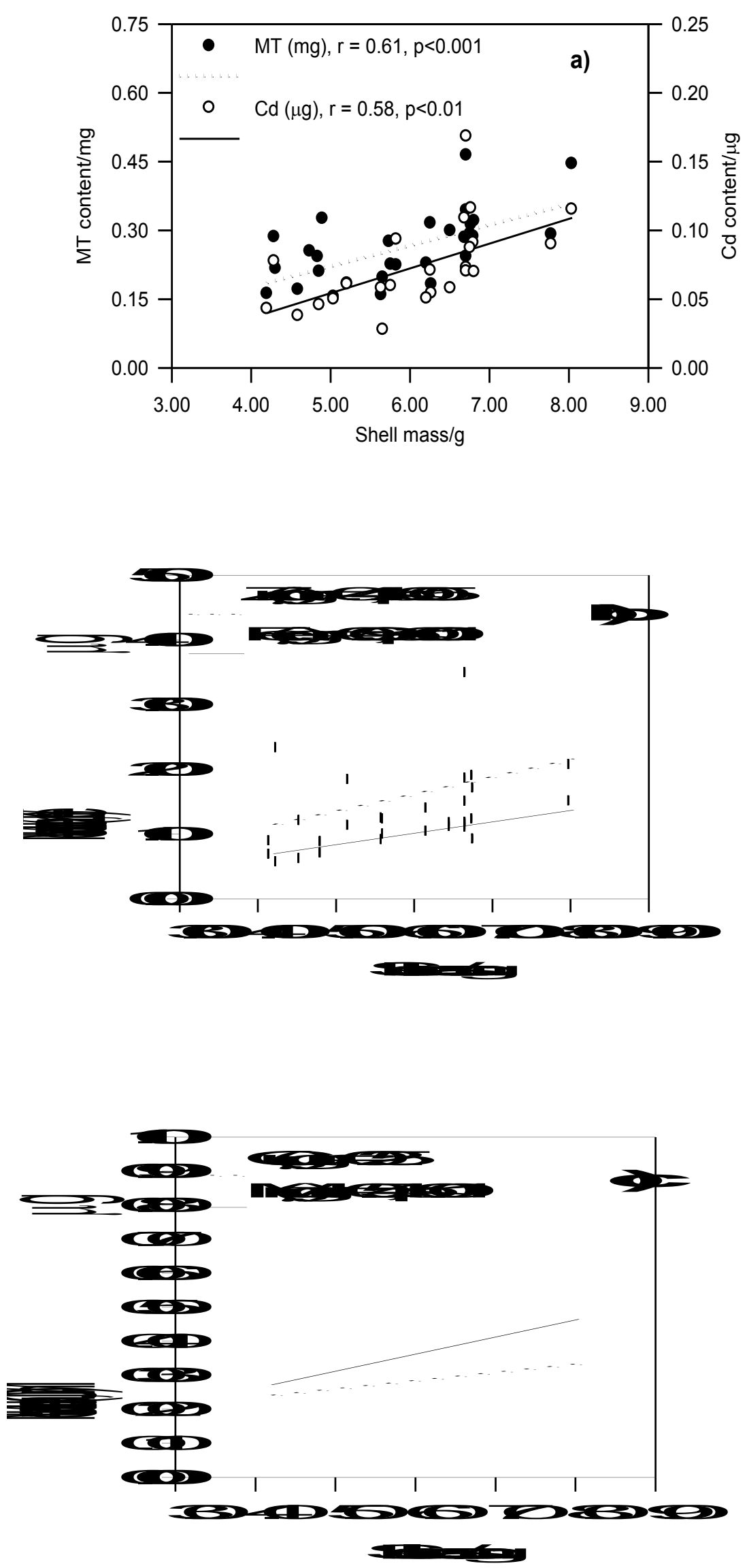


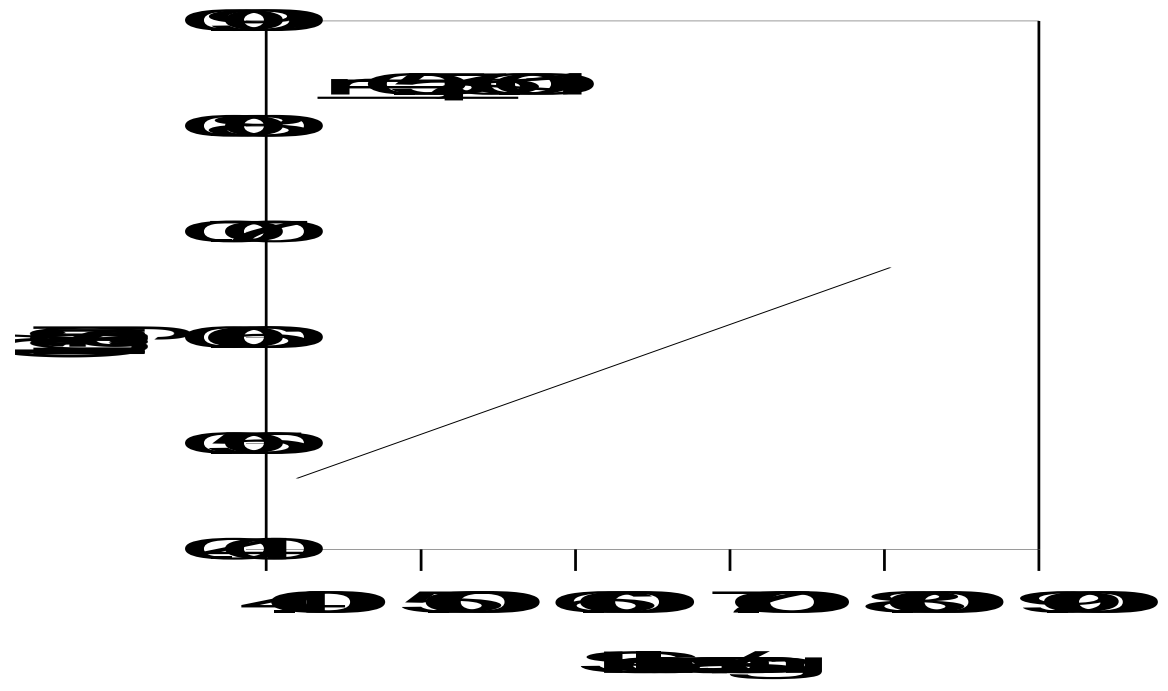



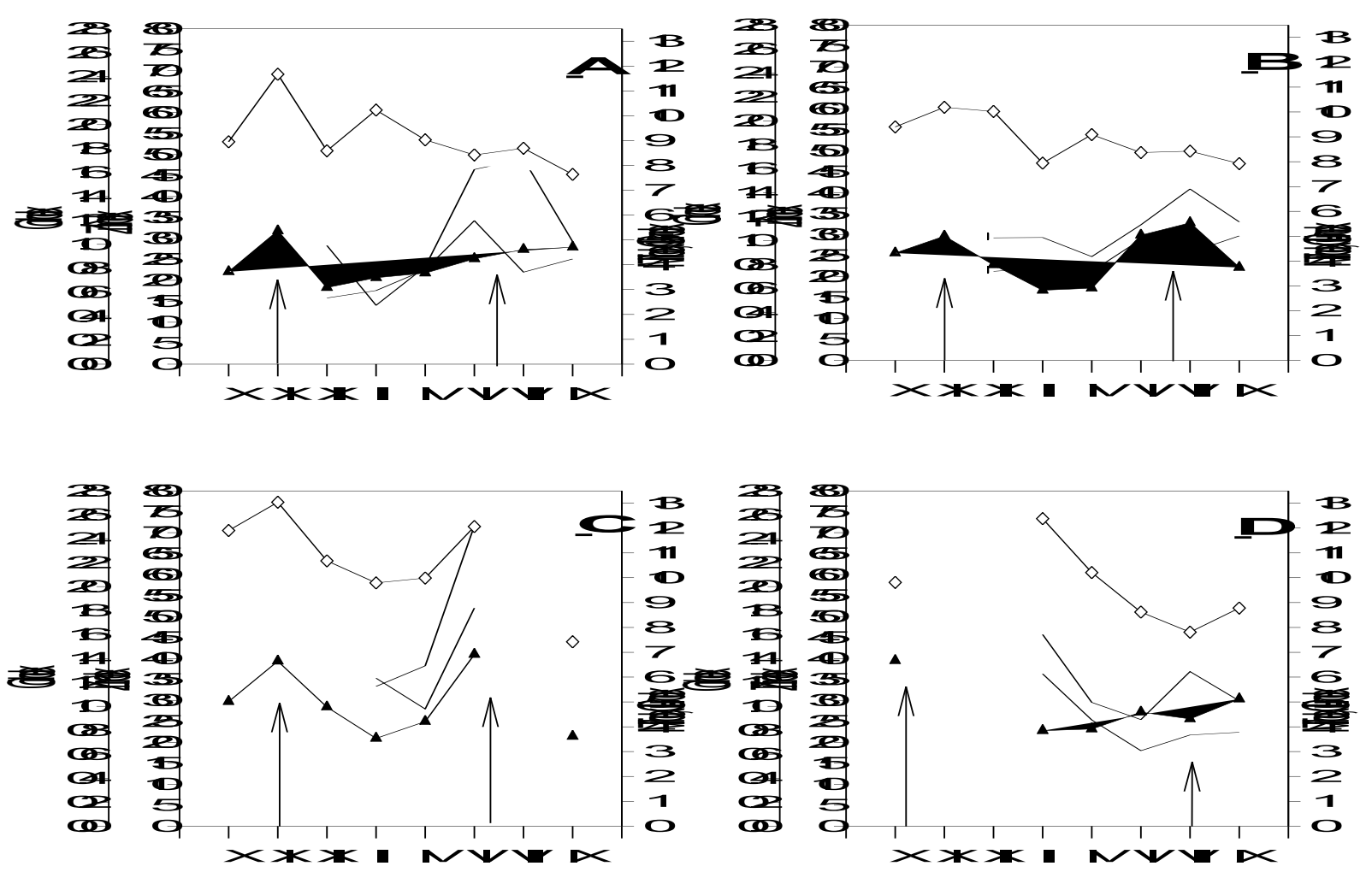


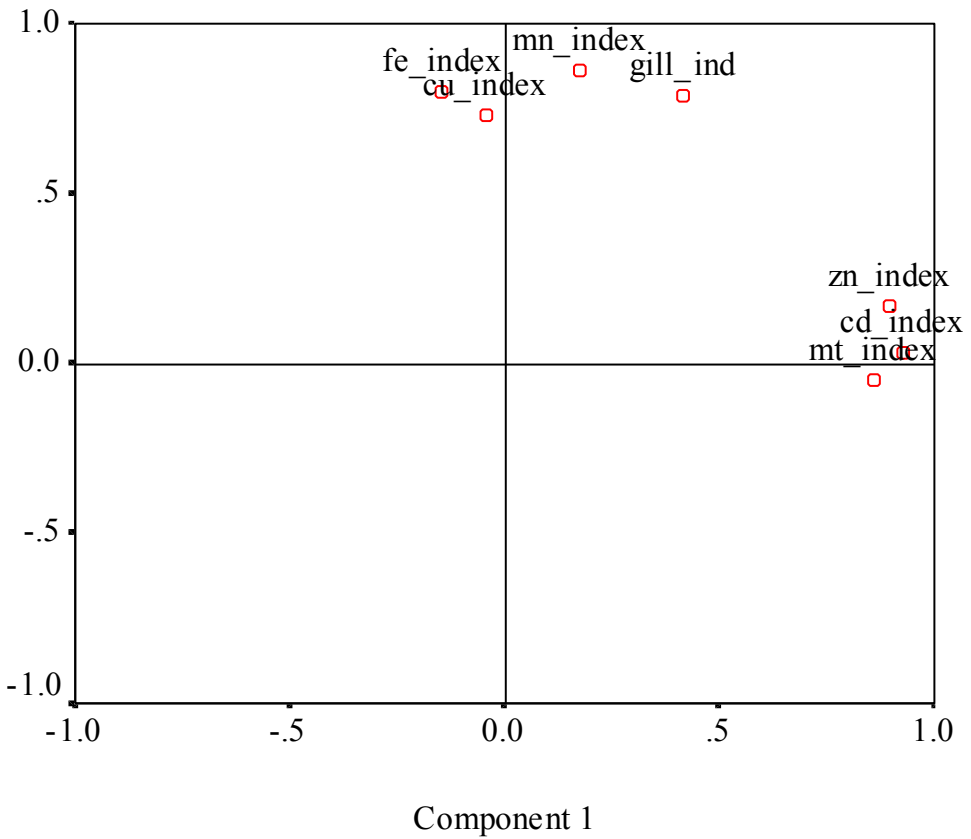

